https://doi.org/10.15407/ukrbotj76.05.390

\title{
Infraspecific molecular trees are associated with serial macroevolution in Pottiaceae (Bryophyta)
}

\author{
Richard H. ZANDER
}

Missouri Botanical Garden

4344 Shaw Blvd., St. Louis, Missouri 63110

richard.zander@mobot.org

Zander R.H. 2019. Infraspecific molecular trees are associated with serial macroevolution in Pottiaceae (Bryophyta). Ukrainian Botanical Journal, 76(5): 390-405.

Abstract. The analytic orientation of this paper is intended as a replacement for the antiquated but still prevalent phylogenetic inferential models and techniques of the late $20^{\text {th }}$ century that are focused entirely on shared descent. Serial descent, that is, progenitor to descendant, may occur at the species or infraspecies level. In molecular systematics, species level paraphyly occurs when two examples of the same species are separated on a cladogram by a second species. This implies linear macroevolution of the second species from the first. Molecular cladograms often show cladistic structure (branching) among examples of the same species. If well-supported, such indicates a potential for evolution. A range of infraspecific and intraspecific cladistic structure in species of Pottiaceae (Bryophyta) was demonstrated in previously published molecular cladograms and data sets of other authors. This includes well-supported cladistic structure of molecular strains, and well-supported paraphyly involving other species. Large numbers of base pair changes among strains are considered here evidence of evolvability and increasing age of a species. Infraspecific strains are apparently lost in older species through speciation and extinction. Cluster analysis using DNA metadata of Oxystegus species matched published molecular cladograms to a large extent. The fact that apparent molecular strains are present in both nonparaphyletic and paraphyletic species, about half the species studied, shore up the theory that internal racial differentiation at the molecular level leads to or signals serial descent of multiple extant morphotaxa. It is because much infraspecific molecular cladistic structure exists that newly speciated taxa are already strongly cladistically dichotomized. Thus, the ultimate source of molecular paraphyly is internal to each species, and does not imply polyphyly by convergent species or cryptic taxa. Molecular systematics cannot effectively model progenitor-descendant radiation. Species with many strains are potential sources of future biological diversity. Recognition of differential evolvability may allow facilitation of complex, interactive, diverse ecosystems successfully tracking climate change.

Keywords: age, Bayesian posterior probabilities, cladogram, linear descent, macroevolution, metadata, paraphyly, presorted molecular strains, races

Submitted 29 July 2019. Published 31 October 2019

Зандер Р.Г. 2019. Внутрішньовидові молекулярні дерева пов'язані з послідовною макроеволюцією у родині Pottiaceae (Bryophyta). Український ботанічний журнал, 76(5): 390-405.

Міссурійський ботанічний сад,

Сент-Луїс, Міссурі 63166-029 США

Реферат. Аналітична спрямованість цієї статті полягає у прагненні замінити застарілі, але все ще поширені філогенетичні моделі та методи кінця 20-го століття, які повністю базуються на концепції спільного походження. Послідовне походження, тобто від попередніх предків до нащадків, може відбуватися на рівні видів або внутрішньовидових таксонів. У молекулярній систематиці парафілія на видовому рівні має місце тоді, коли два представники одного виду розділені на кладограмі іншим видом. Це означає послідовну (лінійну) макроеволюцію другого виду від першого. Молекулярні кладограми часто демонструють кладистичну структуру (галуження філогенетичних ліній) серед зразків одного виду. За умов високої підтримки, це вказує на еволюційний потенціал. Спектр міжвидової та внутрішньовидової кладистичної структури у видів родини Pottiaceae (Bryophyta) був продемонстрований у раніше опублікованих молекулярних кладограмах та даних інших авторів. Це включає добре підтримувану кладистичну структуру молекулярних ліній та добре підтримувану парафілію щодо інших видів. Значна кількість змін нуклеотидних пар серед ліній одного виду у такому випадку вважається тут свідченням еволюційної спроможності та збільшення часу існування виду. Внутрішньовидові філогенетичні лінії у старших за віком видів, очевидно, втрачаються через видоутворення та вимирання. Кластерний аналіз із використанням метаданих ДНК видів Oxystegus значною мірою збігається з опублікованими молекулярними кладограмами. Той факт, що очевидні молекулярні лінії наявні як у непарафілетичних, так і у парафілетичних видів (загалом приблизно у половини з досліджених видів), підтверджує гіпотезу про те, що внутрішня расова диференціація на молекулярному рівні призводить до послідовного походження багатьох нині існуючих морфотаксонів, або ж свідчить про цей процес. Новоутворені таксони вже є сильно кладистично дихотомізованими саме тому, що у межах предкових видів існуює значна внутрішньовидова молекулярна кладистична структура. Таким чином, основне джерело молекулярної парафілії є внутрішнім феноменом для кожного виду, а тому воно не обов'язково свідчить про поліфілію завдяки ймовірному існуванню конвергентних видів чи криптичних таксонів. Молекулярна систематика не може ефективно моделювати диверсифікацію у системі "предок-нащадок". Види з багатьма філогенетичними лініями є потенційним джерелом майбутнього біологічного різноманіття. Визнання диференційованої еволюційної спроможності може сприяти утворенню та розвитку складних, інтерактивних, різноманітних екосистем, які успішно реагують на зміни клімату.

Ключові слова: байєсова апостеріорна ймовірність, вік, диференційовані молекулярні лінії, кладограма, макроеволюція, метадані, парафілія, послідовне походження, раси

(C) 2019 R.H. Zander. Published by the M.G. Kholodny Institute of Botany, NAS of Ukraine. This is an open access article under the terms of the Creative Commons Attribution License (http://creativecommons.org/licenses/by/4.0/), which permits use, distribution, and reproduction in any medium, provided the original work is properly cited 


\section{Introduction}

In the past few years, genera of the moss family Pottiaceae have been analyzed with macroevolutionary methodology (Zander, 2013, 2019a) to infer serial evolution (Jenner, 2018) of stem taxa on a branching tree or caulogram. These include Anoectangium (Zander, 2017a, 2019a), Didymodon (Zander, 2014a,b,c, 2016), Exobryum (Zander, 2019b), Leptodontium s.lat. (Zander, 2018), and Oxystegus (Zander, 2017b).

The analysis of these taxa was essentially morphological with the explanation that molecular paraphyly, both extinct and extant, confounded evaluation of evolution by expressed traits. The value of molecular phylogenetics in tracking actual speciation was limited to molecular paraphyly that implied progenitor-descendant serial evolution (Brummit, 2002, 2008; Dayrat, 2003; Hörandl 2010), and sufficient distance on a cladogram such that nonmonophyly was probable, i.e. molecular paraphyly probably did not overlap between species. Was this justified? The concept of a dissilient genus (radiating descendants from a progenitor) presupposes multiple generation of daughter species. What evidence for the practicing taxonomist is there supporting multiple radiation of descendants? That is, aside from direct study of population genetics. Examples of identification of paraphyletic taxa as ancestral are given by Futuyma (1998: 456, 470), who cited Moritz et al. (1992), where coastal and Sierran Californian subspecies of the salamander Ensatina eschscholtzii appear to have been derived from subsp. oregonensis. Rieseberg and Brouillet (1994) discuss mechanisms for evolution of monophyletic daughter taxa from paraphyletic parental taxa through geographically local models of speciation.

The macroevolutionary analysis of Didymodon species by Aubert (2017) derives a caulogram using a computerized methodology involving replacing nodes on a morphological cladogram of maximum parsimony with extant ancestors in the data set, with estimates of character reliability using a consistency index. Aubert asserted that his parsimony method is more explicit (more algorithmically constrained) than that of Zander, whose method relies on expert familiarity with trait stability. The lability of traits used by Aubert, however, was evaluated with the number of trait transformations in a cladogram by consistency index and successive weighting, and his analysis is founded on a cladistic tree involving the splitting of sets of traits, not a process in nature. Quite positively, however, his results for
Didymodon were much like those of Zander (2013, 2014a,b,c). The number of appearances of a trait among related species (not nodes, but species), in my opinion, is certainly of importance in determining the degree of serial nesting of species, and Aubert's contribution is of considerable interest. Aubert's method ignores, on the other hand, the identification of closed causal groups (Zander, 2018: 36) that eliminate much irrelevant data from consideration.

The present paper evaluates data from previously published molecular cladograms, and also comparison of actual sequences from two or more exemplars of the same species in an attempt to investigate the connection of infraspecific cladistic structure with paraphyly in a systematics context. If cladistic structure (meaning a branching clade) equivalent to paraphyly (Funk, Omland, 2003) can be shown to be exhibited between molecular strains of the same species, at times including different species among the strains and even different genera, then the mechanism of molecular strains of the same species giving rise to different species or even different genera as suggested by Darwin (Haskell, Adhikari, 2009) is supported as an evolutionary process. Increasing numbers of tracking traits should parallel increasing numbers of neutral mutations with potential for future adaptive evolution (Lee, Marx, 2019). This also supports the idea that molecular paraphyly implies ancestor-descendant serial generation of species, and advances the concept of the dissilient (radiative) genus (Zander, 2013: 92, 2018: 170) as an empirically supported scientific reality.

There are, of course, alternative processes that affect intraspecific differentiation, such as lateral gene transfer, reticulate evolution, and hybridization (Gophna, 2013; Ignatov et al., 2019; Morrison, 2014; Thompson, 2013: 323), and future study may well involve network analysis (Morrison, 2010). This is, however, a first look at what evidence we have in support of molecular strains as critical for serial interpretations of evolution in Pottiaceae.

The process is serial macroevolution, in phylogenetics ascribed to a short-term incomplete differentiation of two new species from an unknown shared ancestor (lineage sorting). Phylogenetic interpretation is here criticized as based on shared descent alone with the methodological necessity of disappearance of a shared ancestor. Extant or extinct or unsampled molecular paraphyly, however, explains much incongruence between morphological and molecular cladograms or other diagrams of evolutionary relationships. This 
paper attempts to demonstrate a range of paraphyly from simple or well-supported infraspecific cladistic structure through species level paraphyly and shortrange molecular apparent polyphyly using metadata from other authors' previously published molecular studies of taxa in the moss family Pottiaceae (Bryophyta). Short-range apparent polyphyly is simply paraphyly encompassing two or more apophyletic (descendant) species in a cladogram. Strains of taxa as tracked by molecular mutations are here considered the fundamental ground of biodiversity (Haskell, Adhikari, 2009).

In macroevolutionary systematic analysis (Zander, 2013, 2014a,b,c, 2016, 2019a,b), information from morphological analyses is preferred over that of molecular data. This is because variation in molecular data from different samples of the same taxon is common, while there is no species concept entirely native to molecular data beyond cladistic clustering of similar sequences. The species concept used in the present study is that of the standard taxonomic morphospecies. Because geographic distribution and substrate preference are also at least indirectly relevant, a morphospecies is perhaps better termed a "phenospecies" alluding to the use of all expressed traits.

In addition, Bayesian support for morphologically based serial evolution can be very strong (Zander, 2016, 2018: 31, 174). If molecular variation is more than just simple heterozygosity, it may reflect somewhat isolated molecular strains that propagate through serial descent. Evidence for this is cladistic structure at the infraspecies level. If demonstrably well-supported as distinct, and geographically or otherwise well-isolated, then the populations may be termed strongly supported. Most papers on molecular variation, that which is not particularly correlated with clear species differences in expressed traits, have to do with gene differences within a species, or with molecularly based cryptic species (Shaw, 2000, 2001; Shaw et al., 2003).

Molecular cladograms of the authors of papers having to do with the Pottiaceae have in the past been examined (Zander, 2008a,b; 2009, 2010, 2013; 2014a,b,c) for two kinds of evolutionary information helpful in devising an evolution-based classification. (1) Heterophyly, meaning paraphyly or short-range apparent molecular polyphyly, which is taken to imply serial macroevolution, that is, one taxon giving rise to another of equal or higher rank. (2) Patristic distance, in which two exemplars, species or genera are sufficiently distant on a molecular cladogram that paraphyly through extinct or unsampled molecular strains is doubtful, and therefore contrary morphological conclusions must be re-evaluated. Properly, this should be "distance with an excuse," such as extreme reduction that masks morphological traits tracking linear relationships.

Past evidence from inspection of published cladograms. Evidence of molecular strains often includes incongruence of morphological and molecular cladograms, sometimes difficult to assess because of phylogenetically imposed taxonomic splitting and lumping by previous researchers. Absence of molecular strains should be characteristic of recently evolved species or of ancient species with much extinction of strains and biotypes. Moderately old species are more likely to have geographic strains because isolation and drift should be able to establish unique sets of DNA sequences in the separate populations.

The possibility of informative heterophyly (two or more molecular strains somewhat distant on a cladogram with branches of other taxa between) that is now extinct may be judged by (1) the frequency of paraphyly among extant species (as viewed by inspection of cladograms), and (2) the degree of sequence variation in taxa that are molecularly monophyletic (by comparing actual sequences). For instance, several exemplars of one species can all end terminally in a group in a cladogram but may have multiple variants among the DNA tracking traits sampled. Variation is determined on a cladogram by dichotomous branching (i.e., not a multifurcation) among three or more of the exemplars of the species. which implies shared traits, or by looking for differing sequences.

A range of possible effects of variation in molecular sequences in a phylogenetic tree is given in Figure 1. These cladograms are contrived, and are of two, three or four samples, being part of an imaginary larger cladogram of other species not shown. Examples A through $\mathrm{F}$ are of specimens of the imaginary species Aus bus (see Clark et al., 2009). Examples G and $\mathrm{H}$ add one or two species of other taxa. Examples $\mathrm{C}$ through F imply infraspecific paraphyly, the beginning of a monophyletic series. Because well-supported, examples E and F suggest a series of one strain microevolutionarily descending from another. Examples $\mathrm{G}$ and $\mathrm{H}$ imply intraspecies paraphyly as a macroevolutionary series.

In detail, example A shows clustering of two samples of Aus bus, with no indication of molecular variation. Example B is a multifurcation implying the three samples of Aus bus have identical sequences, which is 

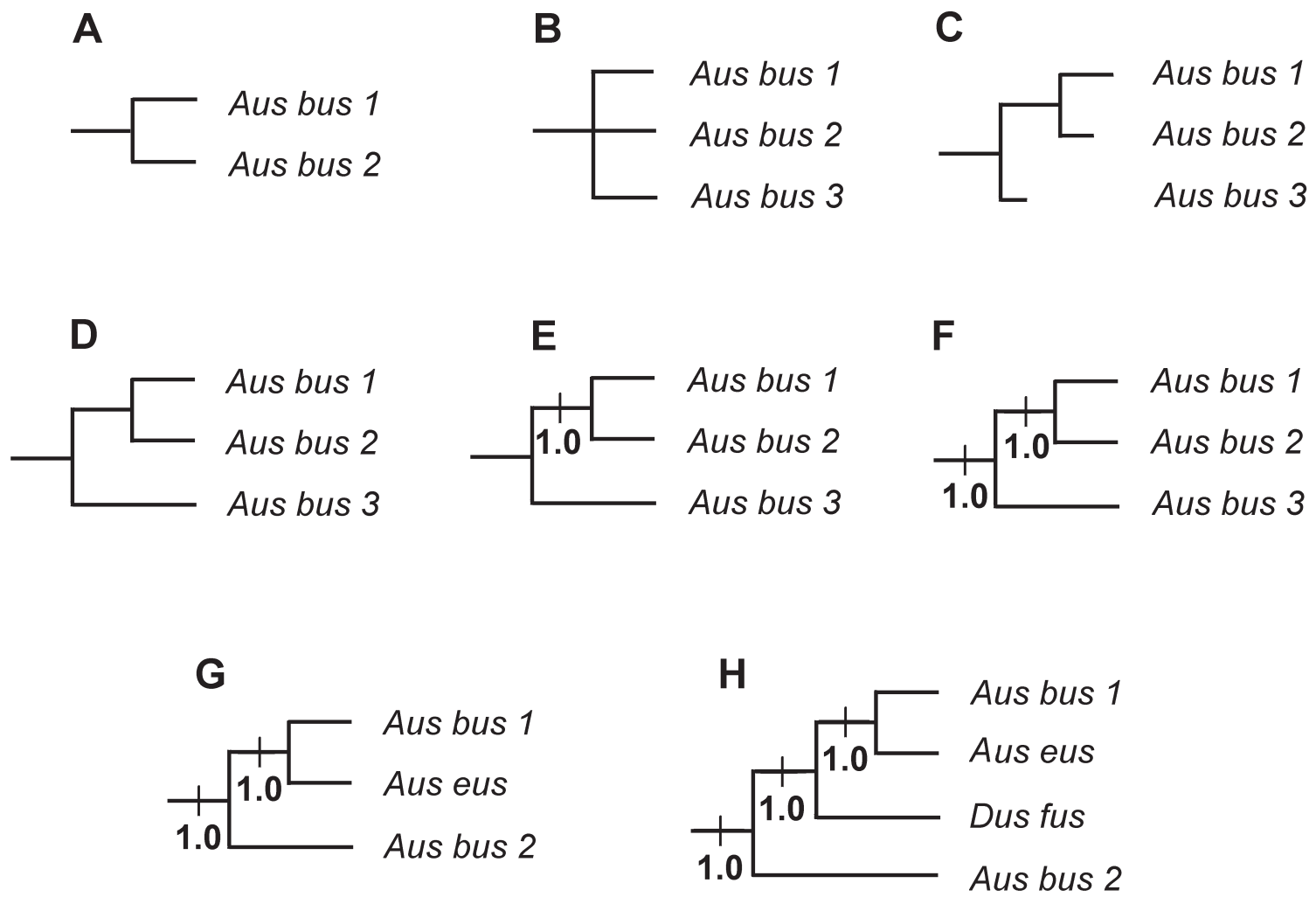

Figure 1. Evolutionary processes inferred from inspection of molecular cladograms. A, B: Samples of the same species with identical or unshared if different sequence data. C, D: Cladogram structure with indication of molecular variation between the samples (C is a phylogram). E, F: Strong support for molecular strains or races possibly tracking infraspecific evolution of expressed traits. G, H: Heterophyly (paraphyly and short-distance apparent molecular polyphyly) implying linear macroevolutionary transformation at the species and genus levels. See text for details

in fact rare. Example $\mathrm{C}$ is a phylogram with different terminal branch lengths reporting variation in the molecular sequences. Example D is a cladogram that implies that sample 1 and 2 are more similar to each other than to sample 3 . This may occur simply with one base change, which would leave the other two identical and only apparently possessing a synapomorphy. The structure of Example E, however, does demonstrate wellsupported (1.00 BPP) molecular variation in species Aus bus, where BPP is Bayesian posterior probability. Example E has Bayesian posterior probability support of statistical certainty (unity). This means that samples 1 and 2 share sufficient shared traits that these are not probabilistically due to random variation, but imply shared infraspecific ancestry. These may be at least tentatively termed two races, particularly if there seems to be a geographic difference between strains. This indicates that mutations are tracking microevolution.
Example $\mathrm{F}$ shows that strain 3 is part of the variation of Aus bus and not to be confounded with another sample elsewhere in the cladogram but not shown. Example $\mathrm{G}$ shows molecular paraphyly of Aus bus, suggesting that it is the direct ancestor of the species Aus eus. Example $\mathrm{H}$ shows short-distance apparent molecular polyphyly. In this case, both Aus eus and a species of a different genus, Dus fus, need to be examined to see if a hypothesis of linear macroevolutionary transformation may be applied at both the species and genus levels by examining information not in the molecular data set.

If the data reflect the kinds of evolutionary processes detailed in Figure 1, then it may be concluded that there is infraspecific paraphyly or microevolution that is part of the process of serial macroevolutionary generation of a species from an ancestral species extant today. Also, it is then possible that such infraspecific paraphyly, if extinct or unsampled, can contribute to incongruence between 
Figure 2. UPGMA cluster analysis with Euclidean similarity index for Oxystegus species and strains. Aligned nrITS sequence data from Alonzo et al. (2016) were imported into PAST (Hammer, 2018). Infraspecific strains have numbers of site changes gradually ranging from zero to equal to numbers of differences between species. The species Oxystegus recurvifolius and $O$. tenuirostris (in boldface) overlap in being analogically paraphyletic to $O$. daldinianus and $O$. minor in this evaluation of overall similarity of sequences. The former two species may be inferred to be ancestral to the latter two, with $O$. recurvifolius being most ancestral in the lineage

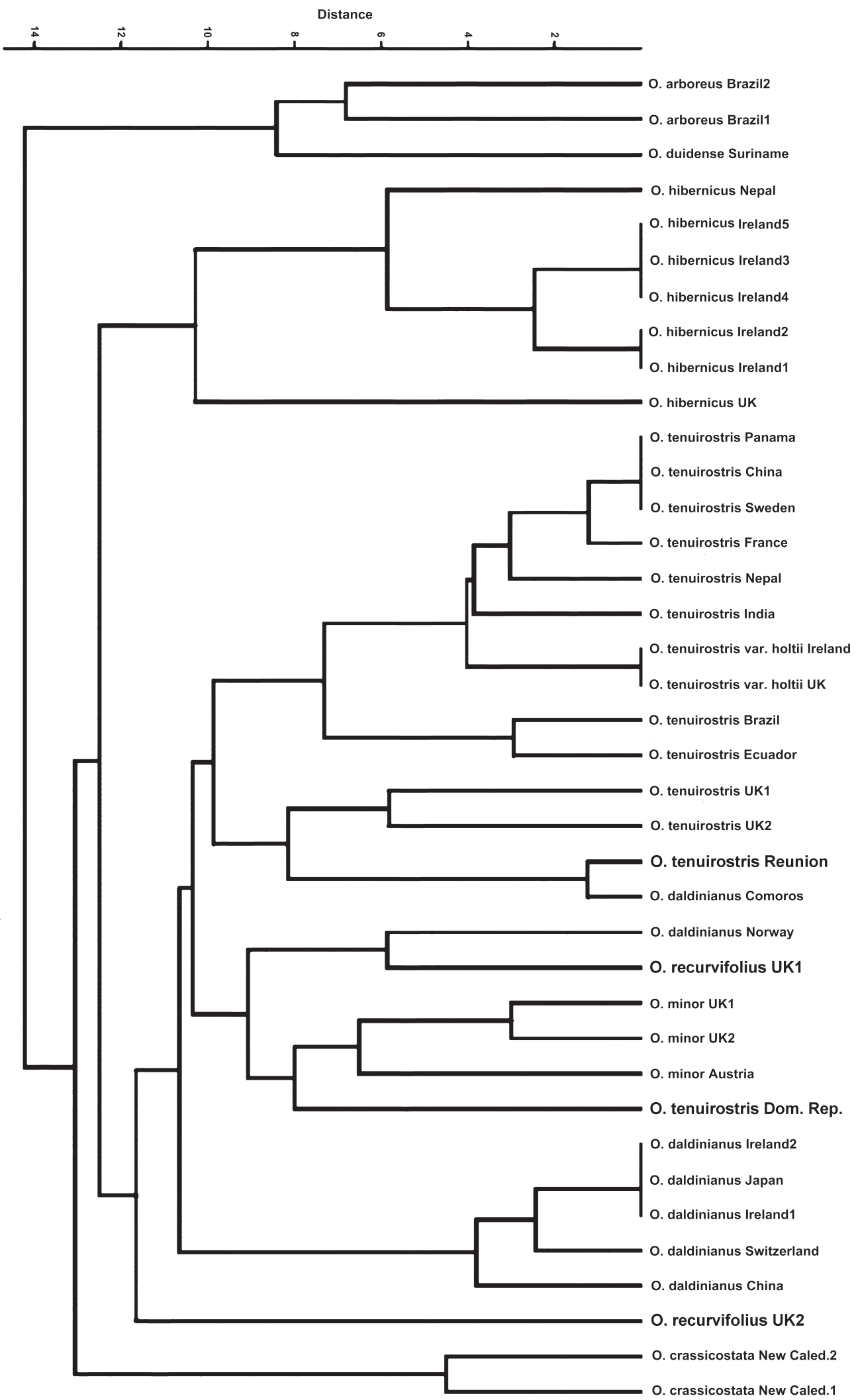


molecular and morphological cladograms. If paraphyly is commonly extinct or unsampled, then imposition of strict phylogenetic monophyly is inappropriate as a basis for classification.

Evidence of possible molecular strains was given inadvertently by Grundmann et al. (2006) in a molecular study of taxa related to Pleurochaete (Pottiaceae). Using data from a combined nrITS and cpDNA data set (concatenated analysis), several species had branches within their monophyletic group. For Chionoloma bombayense, what might have been a molecular race in Malawi was separated from one in Comores; this data, however, is doubtful as it is based on wrong identifications of specimens at (BM), see discussion of Werner et al. (2005) below. For Pleurochaete squarrosa, three strains were distinguished, one for North America, one for Germany, and another for a broad area in Europe. Tortella fragilis evinced distinct molecular differences between Russia and Greenland, while $T$. flavovirens showed distinctions between Spain and Australia. Tortella tortuosa demonstrated possible microevolutionary evolution with exemplars from Canada (British Columbia and Newfoundland) paraphyletic to one from Italy. There was no macroevolutionarily informative taxon-based heterophyly.

Spagnuolo et al. (2009) published a study sampling molecular genetic variation in Mediterranean populations of Pleurochaete squarrosa in which considerable inter- and intra-population diversity was noted with some cladistic structure.

Werner et al. (2014) produced a cladogram of a nrITS study of various species of Tortella that showed considerable well-supported cladistic structure in Tortella flavovirens, namely (1.00 Spain (1.00 Greece (0.97Australia, Netherlands))), with BPPs given in boldface. Note the geographic disjunction of the Australia and Netherlands strain (or if two strains, then at least the shared portion of the sequence). The specimens from Spain, Australia and the Netherlands were identical to those used in a previous publication by Grundmann et al. (2006), thus the similar branching pattern is not an independent sampling.

The study of Barbula (Pottiaceae) by Kučera et al. (2013) is somewhat more informative in that their cladogram is a phylogram that shows, with different length branches, differences between any two sister group strains of the same species. Unfortunately, few duplicates at the species level were included. Examination of the phylogram for the rps 4 dataset revealed little heterophyly but considerable dichotomous branching within species, including differences between terminal sister-group pairs. Implied molecular strains may be noted for Barbula indica (Australia versus India), $B$. gregaria (Mexico versus India), and $B$. unguiculata (Austria versus USA).

A relevant metadata study. Studies by molecularly oriented systematists have revealed numbers of molecular strains within species of bryophytes. A metadata study has been conducted by Zander (2019b) of the number of molecular strains per species in the Pottiaceae (these all termed "races" in that study). The data for this study was based on several recent publications (Alonso et al., 2016; Cano et al., 2009; Grundmann et al., 2006; Köckinger et al., 2010; Kučera, Ignatov, 2015; Kučera et al., 2013, 2018; Werner et al., 2005, 2009, 2014). Molecular strains were inferred when two exemplars of the same species share at minimum one trait not shared by a third exemplar of the same species, i.e., an internal node with two exemplars terminal and one more basal. These species were called "multiracial." Molecular paraphyly was identified as a different species inserted on a node between two exemplars of one species, each then taken as a separate molecular strain. All entries that showed no evidence of molecular strains were ignored because they either were of one exemplar or the branches to several exemplars of one species are multifurcations without internal branches. Because cladograms only recognize shared traits, only a multifurcation to multiple exemplars of a single-species with one or more internal branches was taken as evidence of more than one molecular strain.

The study (Zander, 2019b) by inspection of cladogram structure (ignoring geographic ranges) showed 71 entries of multiracial species including 46 different species. The total number of molecular strains among the 46 multiracial species was 208. The average number of molecular strains for the 46 species (i.e., the number of internal cladogram nodes interpretable as signaling differently composed sequences in any one species) was $\mathbf{4 . 5 2}$, for both paraphyletic and nonparaphyletic species.

The total number of paraphyletic instances among the 71 entries was 29. The number of paraphyletic species was 22, or $\mathbf{0 . 4 1}$ of the 46 different known (from cladogram structure) multiracial species. The number of different apophyletic species (those on a lineage distal to a paraphyly) in all sequences was 79 . The average number of apophyletic species per paraphyly was 
3.59. A total of 133 nodes were maximally distant (on the cladogram) between paraphyletic exemplars. The average number of nodes between maximally distant paraphyletic exemplars of the same species was 4.50 .

Thus, (1) large numbers of species have molecular strains, (2) those with sufficient data to determine the numbers of molecular strains average 4.52 molecular strains, (3) a large percentage (0.41) of all demonstrably multiracial species are also paraphyletic, (4) the many apophyletic species (an average of 3.59) per paraphyly indicate that an inferred progenitor-descendant relationship commonly involves many species or multiple radiation from one ancestor, and (5) the large number of nodes between most-distant paraphyletic exemplars of the same species (4.50) implies that phylogenetic differences between species on a molecular cladogram must take into account possible paraphyly by extinct or unsampled material of any one species. This means that every species represented by only one exemplar on a molecular cladogram must be expected to have a circle of possible paraphyly, i.e., of monophyletic uncertainty, of an average of 4.5 contiguous nodes in all directions.

Past evidence from direct sequence comparison. Prior study (Zander, 2013: 62) of sequence data published by other authors indicated that there was often considerable molecular variation among specimens of the same species. Examination of the Werner et al. (2004) aligned data set for their chloroplast rps 4 molecular study of the Pottiaceae, which was graciously provided by Olaf Werner, showed that Anoectangium aestivum and Gymnostomum viridulum differed by seven sites (2 first position, 2 second, 3 third), while Erythrophyllopsis andinum and $E$. zanderi differed by six sites (3 first position, 1 second, 3 third). On the other hand, the two exemplar specimens of Splachnobryum obtusum (the only species of which two specimens were analyzed) differed by fully 21 sites (4 first position, 7 second, 10 third). Although the rates of transformational changes at sequence sites, especially in the codon, surely differ, variation between exemplars of the same species in the same studied sequence is informative. It is doubtful that the two samples of $S$. obtusum are not in the same species, or that $G$. viridulum is a misidentification. Clearly, molecular variation in a cladogram within a species may be unappreciated evidence of the age of the species and of possible extinct strains. Throughout this paper, authorities for the taxonomic names given may be found in the papers cited.

\section{Materials and Methods}

Pre-aligned sequences, on which previously published molecular cladograms of the Pottiaceae (Alonso et al., 2016; Cano et al., 2009; Werner et al., 2005) were based, were kindly made available to the present author. These were examined for evidence of molecular variation that may imply operation of an evolutionary process. Also, infraspecific evidence of cladistic structure was taken to imply serial descent of molecular strains. Such evidence, especially if associated with geographic disjunction, is indication of molecular races (coherent allopatric sets of strains) that imply past or present speciation.

There are two sources of information on molecular cladistic structure. First, simple inspection of a cladogram may show branching in a lineage leading to three or more exemplars of one species. This implies that two exemplars share at least one trait not found in a third. Second, direct comparison of DNA sequences allows discovery of differences between infraspecific sequences that represent populations with at least that amount of distinction. Species that either show complex branching on a cladogram or are clearly distinct in actual DNA base pairs are both termed here multiracial, whether well supported or not. Sometimes one or more different species are inserted among the branches from one species. That one species is termed paraphyletic, and the evidence implies it is ancestral to species in the same lineage but which are more distal on the cladogram. These species bracketed by branches on the cladogram are termed apophyletic species, meaning descendant in a phylogenetic context.

The same sequences for exemplars of the same species were checked for molecular variation between exemplars and between geographic regions. The examination technique was visual inspection. When all bases were given (rather than just exceptions from the first line), the first three letters of the difficult-to-distinguish ATCG were globally changed to ., |, and x (full stop, vertical bar and the letter $\mathrm{x}$ ). Microsoft Wordpad was used with word wrap off to visually compare lines. Rows of exemplar data of the same species were "selected" to render them in blue for ease of comparison and scoring of differences. Only those DNA sites with bases evident for all samples of a species were scored, that is, a gap in any one of the exemplars of the same species eliminated that DNA site. Total differences were divided by number of exemplars to determine average number of base changes per species.

Ukrainian Botanical Journal, 2019, 76(5) 
Table 1. Metadata information on species with infraspecific cladistic structure from publications of various authors, showing support and amount of variation. Provided are species name; first author and date published; molecular sequence; Newick format cladistic structure and collecting localities of samples (some abbreviated) with Bayesian posterior probabilities in boldface; kind of structure where $\mathrm{S}=$ same sequences, $\mathrm{M}=$ multiracial, $\mathrm{P}=$ paraphyletic; number of exemplars (specimens sequenced); total number of site changes for all exemplars; average number of changes per exemplar for that one species; and total number of sites in sequence. "Combined cpDNA" analysis used $a \operatorname{tp} B-r b c L$, $\operatorname{trn} G$, and $\operatorname{trn} L-F$ data). In the structure column, the locales are given for the name in the second column, and both name and locale for any other taxa included in the clustering

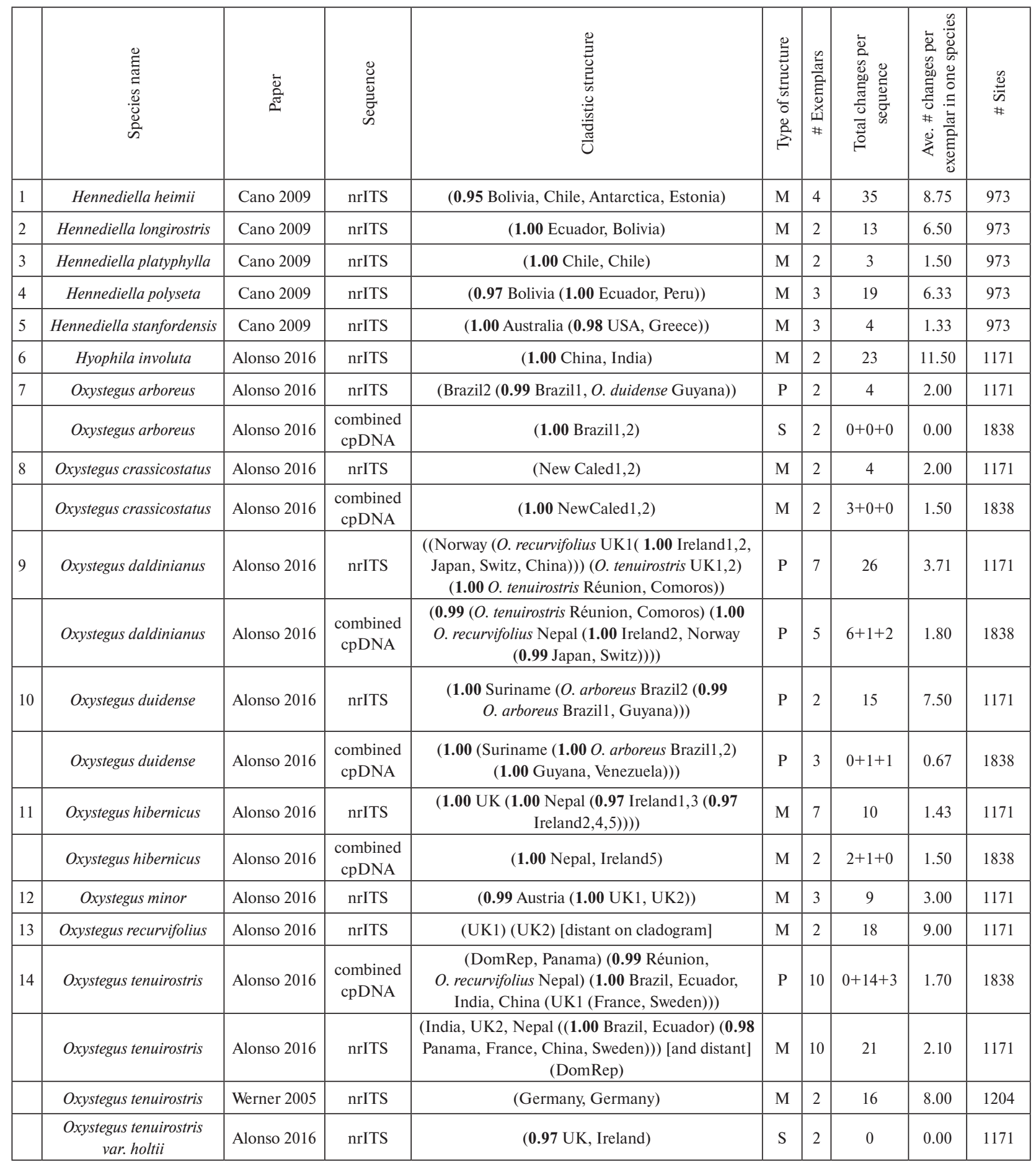




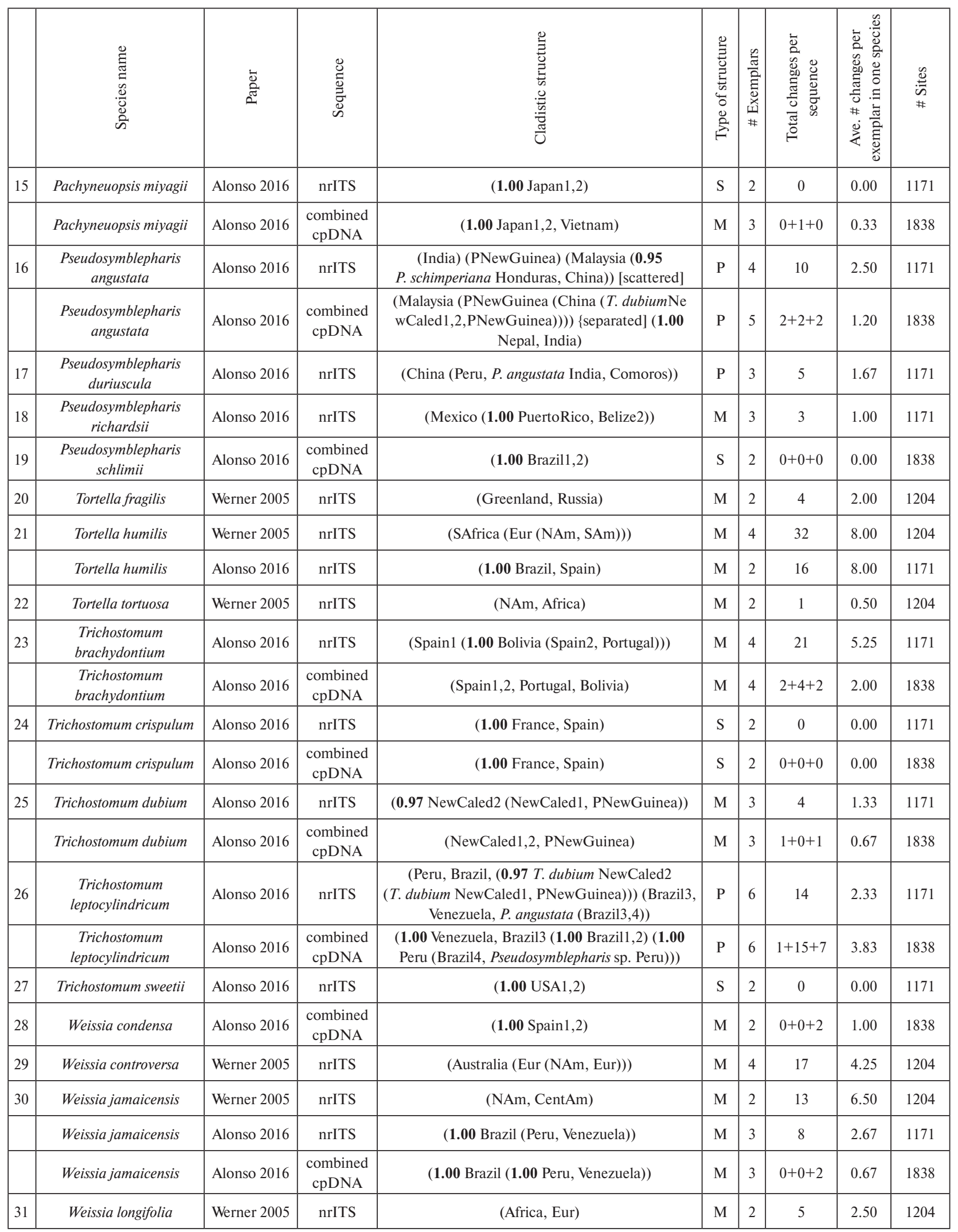


Table 2. Two data structures informative of radiative or linear evolution. Complex 1 shows Species A as progenitor with Species B through E radiating from the progenitor because they have no other shared traits. Complex 2 shows Species F as progenitor, but the remaining species building on shared traits to yield a fully linear progression of progenitors. Numbers refer to different traits or sets of traits that distinguish a morphospecies

\begin{tabular}{|l|l|l|l|l|l|}
\hline Complex 1 & \multicolumn{5}{|c|}{ Traits } \\
\hline Species A & 1 & 0 & 0 & 0 & 0 \\
\hline Species B & 1 & 2 & 0 & 0 & 0 \\
\hline Species C & 1 & 0 & 3 & 0 & 0 \\
\hline Species D & 1 & 0 & 0 & 4 & 0 \\
\hline Species E & 1 & 0 & 0 & 0 & 5 \\
\hline
\end{tabular}

\begin{tabular}{|c|c|c|c|c|c|}
\hline Complex 2 & \multicolumn{5}{|c|}{ Traits } \\
\hline Species F & 1 & 0 & 0 & 0 & 0 \\
\hline Species G & 1 & 2 & 0 & 0 & 0 \\
\hline Species H & 1 & 2 & 3 & 0 & 0 \\
\hline Species I & 1 & 2 & 3 & 4 & 0 \\
\hline Species J & 1 & 2 & 3 & 4 & 5 \\
\hline
\end{tabular}

\section{Results}

The present metadata re-interpretation of other authors' work focused on the moss family Pottiaceae. Data from sequence comparison and from inspection of cladogram branching are given in Table 1.

(1) The first point to be taken is that apparent molecular strains are present in both non-paraphyletic and paraphyletic species. This supports the theory that internal racial differentiation signaled by differences in DNA sequences leads to or is causally associated with serial descent of one or more extant taxa from the paraphyletic taxon. Thus, molecular paraphyly is important information about the evolutionary process, and should not be suppressed by the phylogenetic practices of taxonomic synonymy or splitting into cryptic taxa to preserve strict monophyly. Examples of such unnecessary synonymy and splitting are given by Vanderpoorten and Shaw (2010).

(2) The second major conclusion is that because considerable cladistic structure exists at the infraspecific level, progenitor taxa are already strongly cladistically dichotomized molecularly. Thus, the ultimate source of molecular paraphyly is internal to each species and does not reflect polyphyly. The average number of contiguous nodes that such internal paraphyly spans is 4.5.

(3) A third major conclusion is that molecular analysis cannot track multiple radiation from a single progenitor, because any one progenitor has its strains molecularly already pre-branched and often well supported. The data set in expressed trait (i.e., morphology) macroevolutionary analysis is expected to ideally be a mix of two informative structures, simplified in Table 2. Complex 1 shows Species A as progenitor with Species B through E radiating from the progenitor because there are otherwise no shared traits among the descendants; thus, macroevolutionary formula $=\mathbf{A}>$ (B,C,D,E). Complex 2 shows Species F as progenitor, but the remaining species building on increasingly shared traits to yield a fully linear progression of progenitors; thus, formula $=\mathbf{F}>\mathbf{G}>\mathbf{H}>\mathbf{I}>\mathbf{J}$. Molecular data cannot support or falsify the relationships between morphospecies suggested by Complex 1 in Table 2. This is a major short-coming of molecular analysis because adaptive evolution and distinctive implications of nearly neutral differentiation both occur at the level of expressed traits.

Results from inspection of cladogram structure. Alonso et al. (2016) demonstrated (Table 1) both classical taxon-level molecular heterophyly and intraspecies dichotomous branching indicative of microevolutionary intraspecies heterophyly. Heterophyly at the species level (macroevolution) was shown by Trichostomum leptocylindricum strains in South America generating two strains of T. dubium in New Caledonia and Papua New Guinea. Oxystegus daldinianus in Comoros apparently is closely related to $O$. tenuirostris in La Réunion, and may have been generated from $O$. recurvifolius in Nepal or perhaps elsewhere. Oxystegus tenuirostris exhibited many strains but no informative cladistic structure. Oxystegus arboreus generated Oxystegus duidense and vice versa in confounding data. A microevolutionary scenario is implied by dichotomous branching in Trichostomum brachydontium with European populations apparently generating a different strain in Bolivia, which itself gave rise to another European strain (a dubious result).

An analysis of the genus Hennediella (Pottiaceae) by Cano et al. (2009) using nrITS data found dichotomous branching within the species Hennediella polyseta (Bolivia versus Ecuador and Peru), and H. stanfordensis (Australia versus USA and Greece).

The Werner et al. (2005) study showed Tortella humilis having North and South American strains derived from a European strain, itself derived from a South African strain. It is probable that increased sampling will tell if this is a straight-forward inference or part of a much more complicated infraspecific pattern. The same odd, doubtful geographic relationship is shown with Weissia condensa strains in North America and Europe derived from a different European strain, itself derived from an Australian strain.

Other geographic relationships in cladograms from the Alonso et al. (2016), Cano et al. (2009) and Werner (2005) studies show strains of the same species present in both sympatric (same country), and short and long 
distance allopatric situations. Given the small sample, additional analysis is needed.

Results from sequence comparisons. Recent publications are a source of information on DNA sequence heterogeneity within species. Because a species' published sequences may be reused (e.g., from GenBank sequence database) by multiple authors, the same conclusions in different studies may not be significant in all respects in that differences in branching among different samples of the same species are partially masked by the duplicate data. For instance, the study of Alonso et al. (2016) used 19 sequence samples previously used in the Köckinger et al. (2010) study. All of the possible evolutionary relationships shown in Fig. 1 were found in the data examined. The following discussions are based on the information in Table 1.

Variation was found by Cano et al. (2009) using nrITS data to be extensive among four samples of the species $H$. heimii, with 35 of the 973 sites of the sequence having variation and no gaps. There was no evidence of cladistic structure (as shared variation) or of geographic molecular races in $H$. heimii. Scoring only sites with a variant in one particular geographic locale alone, there were two base changes for Estonia, seven for Antarctica, nine for Bolivia, and four for Chile.

Heterophyly that indicated molecular strains of taxa somewhat distant on a molecular cladogram was quite common in the study of Werner et al. (2005) using nrITS data (Table 1). The cladogram included many taxa of Pottiaceae with duplicate exemplars among the same species. The multiplicity of molecular strains implied by this analysis indicates considerable complexity in evolutionary pathways and, in addition, complexity foreboded by possible extinct molecular strains that further complicate an inferable evolutionary tree.

According to O. Werner (pers. comm.) in that 2005 study, re-identifications post-publication found Chionoloma bombayensis (Malawi) was actually Tortella xanthocarpa; the same from China was Pseudosymblepharis angustata; the same from Comoros was Tortella vernicosa; and the same from South Africa was Tortella humilis. In addition, Trichostomum tenuirostre 2 (Germany) was Tortella bambergeri, T. tenuirostre 3 (UK) was T. tenuirostre 2 (Germany). The sequence data on which the variability in Table 1 was based is for the corrected identifications, and seems firm.

The sequence data given in Table 1 significantly enlarge upon inferences obtained from visual inspection of cladogram nesting:
(1) There were 159 exemplars of 31 species studied, with an average of $\mathbf{2 . 9 2}$ site changes per exemplar. The number of site changes among strains in any one species is large and variable as given in "total changes per sequence", that is, the more exemplars are studied, the more strains are discovered.

(2) Samples of the same species with identical sequence data are uncommon. Three species and one variety (Oxystegus tenuirostris var. holtii, Pachyneuropsis miyagii, Trichostomum crispulum, T. sweetii) showed no nrITS molecular variation, although sampling was small (two exemplars each). The geographic provenances were not globally distant, as most species had only short distances between sample sites.

(3) Eleven species showed molecular variation in the sequences studied but no cladistic structure. The differences may be stochastic, and unrelated as descendant and progenitor.

(4) Cladogram structure with little indication of geographic distinctions between the strains was rare. Two species showed structure in the cladogram implying molecular variation but no strong support against random distribution. These were Tortella humilis and Weissia controversa, globally common and widespread, probably of old distribution, and may represent genetic relicts.

(5) Strong support at Bayes posterior probability of $0.95,0.99$ or 1.00 for molecular races was shown for 7 of the 31 species in the metadata study. The fact that one-fourth of the species demonstrate molecular races supports inference of pre-speciational sorting of molecular lineages. There is some correlation of wellsupported groups and geographic provenance of the samples. Additional study is needed for clarification.

(6) Species level paraphyly and short-distance apparent molecular polyphyly implying linear macroevolutionary transformation at the species and genus levels is found in another 8 of the 31 species studied, again with some correlation of geography and clustering of molecular strains. Thus, 15 of the 31 species, about half, show evidence of DNA changes tracking infraspecific differentiation of populations pre-sorted before speciation. There seems to be sufficient evidence to warrant further study of this implied gradation between infra- and intra-species serial descent.

(7) In Table 1, base changes in DNA sequences of each exemplar of one species are not given. Instead, the relevant information on evolution due to shared traits is given in column 4: cladistic structure. The ten species with the largest average number of site changes 
in nrITS per exemplar were: Hennediella heimii (8.75), Hennediella longirostris (6.5), Hyophila involuta (11.5), Oxystegus daldinianus (7.5), Oxystegus duidense (7.5), Oxystegus recurvifolius (9), Oxystegus tenuirostris (8), Tortella humilis (8), Trichostomum brachydontium (5.25), and Weissia jamaicensis (6.5). These taxa may or may not have well-supported (by BPP) cladistic structure; names of those that do are boldfaced. One might make the tentative conclusion that, given the many accumulated mutations, the light-faced species above are ancient, and, through speciation, have been stripped of well-supported molecularly isolated groups, while bold-faced species are less old, and are still evolving. This complements Darwin's "manufactory hypothesis" (Haskell, Adhikari, 2009) that speciose genera should be comprised of species made up of many varieties or incipient species such that new species are generated from such infraspecific variation.

(8) The Oxystegus molecular species data from the Alonso et al. (2016) study was imported into the software PAST (Hammer 2018; Hammer et al., 2001). Cluster analysis with UPGMA and Euclidean similarity index for the Oxystegus species generated a dendrogram (Figure 2) similar to the cladogram of the Alonso et al. original study as reflected in the formulae for Oxystegus species in Table 1. The same multiple differentiation of infraspecific strains was shown. There was also evident molecular paraphyly (or the analogic equivalent in terms of UPGMA overall similarity of sequences) of Oxystegus recurvifolius with both $O$. daldinianus and $O$. minor as apophyletic, and $O$. tenuirostris paraphyletic to the apophyletic $O$. daldinianus and $O$. minor. One might infer that inasmuch as the range of molecular variation in $O$. recurvifolius is more inclusive than that of $O$. tenuirostris, an initial inference would be that the former is more representative of the more ancient species in the genus.

(9) The aligned sequences of Oxystegus species (Alonso et al., 2016) were shortened by eliminating sites with identical or uninformative data, then they were compared. Differences between species were rather large, mostly by $11-13$ sites, but ranging to 22 (between $O$. hibernicus and $O$. tenuirostris. Differences among infraspecific strains were smaller, largely 0-14 site differences. The number of mutations of infraspecific strains are, as expected, zero ranging to the number of differences shown between species in Oxystegus. From the above observations, molecular heterophyly is a natural additive phenomenon, providing a clue to true monophyly of many species rendered distant on a molecular cladogram.

\section{Discussion}

This paper addresses in part two problems affecting modern systematics. (1) Cladistic analysis is of transformations of sets of shared traits rather than of direct, serial transformation between a known or inferred ancestor and its descendant. (2) Molecular systematics ignores extinct paraphyly as a source of hidden morphotaxon monophyly. Properly, molecular paraphyly implies evolutionarily monophyletic serial macroevolution (taken to an extreme, a series of molecularly paraphyletic species). Several species demonstrate (Table 1) paraphyly of other species among extant strrains, and the extent of such extant paraphyly is an indication of the past frequency of extinct paraphyly. All problems are fundamentally due to a modern reliance on mechanical methods of evolutionary analysis involving hypothetico-deductivism (generating dichotomous cladograms from data on shared descent) as opposed to both deduction and scientific inductive inference involving discursive logic (generating evolutionary trees and filling in missing links from data on direct, serial descent) as described by Zander (2013, 2014a,b,c, 2019).

All the above evolutionary inferences are hypothetical, but hypothesis and theory are the basis for scientific analysis. Acceptable analysis of the directions of macro- and microevolution require indepth sampling and study. The past use of molecular information for creating evolution-based classifications has been to simply treat molecular markers as traits in the classical manner (no matter what technique is used to create the cladograms). It is quite possible that much information may be obtained on evolution if paraphyly were ultimately recognized by phylogenetic systematists as informative of evolutionary direction.

How do we distinguish geographic strains as prespeciation races from simple sympatric heterozygosity? In some cases, molecular variation was found within the same country, giving the possibility that no geographic isolation exists. Genetic heterozygosity may initiate paraphyly, but in itself does not imply separate evolutionary paths-one of which may speciate another taxon and the other not or a different taxon. Isolated molecular strains of the same taxon, however, have that potential. In cladistics, paraphyly is to be methodologically avoided, but in macroevolutionary systematics it is a desideratum as it indicates direction of linear descent, progenitor to descendant. Clearly, dense sampling similar to that done by Spagnuolo et al. 
(2009) or Shaw (2000) is needed. Given great molecular variation among strains, the finding of sufficient similarity in terms of high Bayesian support to separate two terminal strains from a third strain on a lower branch allows the hypothesis that there are indeed molecular races showing microevolutionary linear descent among the variation.

Köckinger et al. (2010: 45) suggested that "high genetic variability often simply reflects the old age of a species. The lack of selection due [in mosses] to mainly vegetative propagation may have led to the co-existence of several ancient and also more modern genotypes over the whole Tertiary distribution area within millions of years." They speculate that the nearly identical ITS sequences of samples of Oxystegus tenuirostris var. holtii is probably due to the young age of the taxon, and they discuss a possibly ancient haplotype for $O$. minor.

Following this line of reasoning, I find it probable that the large variation in the sequences of Tortella humilis and Hennediella heimii, and to a lesser extent Weissia controversa, is due to the great age of these species. There also seems little well-supported infraspecific cladistic structure in these wide-spread and common species. This may be due to descendant species carrying away past cladistic molecular clustering or nesting through speciation or the paradoxically similar process of extinction. It is important to note that the studied sequences are traits that track evolution and are not generally themselves (supposed to be) directly affected by selection (but there are occasionally minor correlation of genetic strains with selection associated with different environments, Magdy et al., 2015). For this reason, molecular traits are not alone appropriate for classification. There is no practical species or genus concept based solely on molecular traits because they may or may not track evolutionarily linked expressed traits. High Bayesian support for taxa clustered by molecular tracking traits is not support for species distinctions representing expressed adaptations to separate evolutionary challenges or even expressed but adaptively neutral fixed distinctions between isolated populations. This is because that support may be for ancient races of a now extinct progenitor.

Molecular variation in Hepaticae. Liverworts, too, exhibit evidence of geographic strains in cladograms. The study of Feldberg et al. (2010) demonstrated internal dichotomous cladistic branching among three or more samples of monophyletic groups of the following species: Cryptocolea pseudocclusa (New Zealand versus Chile versus Argentina), Cuspidatula contracta (Tanzania versus Mauitius), C. monodon (Australia possible microevolutionary derivation of New Zealand population), Jamesoniella purpurascens (heterophyly for a Madagascar strainpossibly generating South African population), J. colorata (Australia versus South Africa versus Chile), Pseudomarsupidium decipiens (Mexico versus La Réunion), Syzygiella securifolia (Indonesia possibly generating Malaysia population), $S$. anomala (Ecuador of 3 strains versus Costa Rica versus Colombia), $S$. tonduzana (Ecuador populations generating Costa Rican population), S. geminifolia (Ecuador versus Tanzania versus La Réunion), S. concreta (four strains in Andes generating Democratic Rep. Congo population), and others not discussed here. There was no classical supraspecies-level molecular heterophyly in spite of the abundant molecular variation and thus no evidence of direct macroevolution. This means either that extinct molecular paraphyly is not a particular issue with this group or that prior nomenclatural enforcement of strict phylogenetic monophyly has hidden it.

This homogeneity is not the case with a molecular study of Lophozia and related taxa by Vilnet et al. (2008). In that sludy of nr ITS1-2 and chloroplast trn $L-F$ sequences, a phylogram revealed much infraspecific cladistic structure, including species level paraphyly. Heterophyly implied the descent of Schistochilopsis incisa from S. opacifolia, Protolophozia debiliformis from L. sudetica, and Lophozia propagulifera from $L$. excisa, and both $L$. schusteriana and L. silvicola from $L$. wenzelii. Molecular divergence of geographically remote populations of some species was discussed by those authors in terms of comparative numbers of substitutions. Except for the anomalous position of $L$. sudetica, one could hypothesize that the genus Lophozia descended from some species of the genus Schistochilopsis, which is an evolutionarily important possibility to be considered but was reported only in the authors' observation that the latter genus is paraphyletic.

\section{Conclusion}

What is the greater import of these findings? The present time is that of an extinction event of increasingly deadly climate change and associated apparently inexorable global catastrophes of extinction, drought, heat waves, wildfires and rising sea levels. To mitigate the effects, science should have a good predictive handle on expected disturbance in the biosphere. This means that 
efforts should be made to estimate future evolution of species and ecosystems as they adapt (or not) to a much changed environment. Clearly, those species that are presently capable of adaptation to expected new conditions must be protected or encouraged. Natural regeneration may be impossible in highly dissected landscapes subject to climate change, and introduction of adapted or preadaptive species may be necessary to promote complex ecosystems.

The recourse is then to resilience ecology (Lake, 2012; Palmer et al., 2006). Simple ecosystem restoration requires a return to a previous state and this implies a no-longer-hoped-for static environment. Given the burning climate crisis and a tide of other disturbances (e.g., Harris et al., 2006; Perry et al., 2015), restoration must take place within a moving target and may never be complete in the historical sense. New concepts are replacing already complex techniques for restoration, including "assisted migration" that attempts to overcome a lack of corridors; "no analogue ecosystems" that, for survival, must integrate otherwise foreign floral and faunal elements; "de-extinction" in which genetic methods recreate or approximate extinct species or resolve regional extirpation with transportation and re-introduction; and a focus on a hoped-for "historical continuity" which rejects a static concept of ecosystems but foresees the establishment of self-sustaining workable complexity changing over time. Thus, "restoration" in context of climate change now necessarily means an aim to support holistically complex, resilient ecosystems not necessarily consisting of historically associated species.

Evolvability is the capacity of a species for adaptive evolution, thus survival of its lineage. This is affected by the hidden evolutionary potential in a species genome, which determines the generation of candidate phenotypes on which natural selection can act. Signs of great evolvability of a species are multiple biotypes, signaled by apparent isolation of multiple strains, races, and subspecies, as discussed in the last chapters of Zander (2018) and by Zander (2019) for Anoectangium (Pottiaceae). Heritable modifications in infraspecific molecular sequences are concomitant with isolation leading to phenotypic variability. A large literature is accumulating on this subject, see Hansen and Houle (2008), Kirschner and Gerhart (1998), Messer et al., (2016), and Pigliucci (2008). Changing ranges of tolerance may be tracked by highly evolvable taxa both anagenetically and through rapid speciation.
Core generative species (Zander, 2013: 83) demonstrating descendant species adapted to a new world climate regime might be distributed or salted in isolated habitats that have largely lost or will have lost their biological diversity. Ancient species of broad range but little genetic variation and evolutionary potential are of less long-term import than species (such as those bold-faced above) that are evolutionarily potent. Some apparently derived or descendant taxa that seem quite specialized compared to their putative extant ancestral species may have evolutionary prospects (Day et al., 2016), and are not evolutionary "dead ends" as suggested by Zander (2013: 81). The apparently highly specialized Hennediella stanfordensis, Oxystegus arboreus, and $O$. duidense are examples showing well-supported cladistic structure. Given the ability of at least the first species to thrive in harsh and arid habitats, these taxa may have important evolutionary consequence for further speciation into a future new world climatic regime. This projection-that future floras are to some extent customizable as new, complex integrations that will change biotype or even species composition while tracking climate change-is under the last-ditch assumption that, in maximally impacted areas, present or newly evolved biotype-rich species may contribute to the long-term mitigation of world-wide impact by expected vegetational and floristic devastation. An integrated biologically multicultural ecosphere will enhance human survival. One might hope that techniques to establish sustainable complexity that reverses climate warming can be developed faster than the time the Earth takes to evolve into a smoking Venus.

\section{Acknowledgements}

I thank Marta Alonso García, María Cano Bernabé, Rosa María Ros-Espín, and Olaf Werner for communication of aligned molecular data sets. Anonymous reviewers contributed valuable suggestions. The Missouri Botanical Garden continues to offer much appreciated opportunity for working on this research.

\section{REFERENCES}

Alonso M., Jiménez J.A., Nylinder S., Hedenäs L., Cano M.J. 2016. Disentangling generic limits in Chionoloma, Oxystegus, Pachyneuropsis and Pseudosymblepharis (Bryophyta: Pottiaceae): An inquiry into their phylogenetic relationships. Taxon, 65: 3-18.

Aubert D. 2017. A simple parsimony-based approach to assess ancestor-descendant relationships. Ukranian Botanical Journal, 74(2): 103-120. https://doi. org/10.15407/ukrbotj74.02.103 
Brummit W. 2002. How to chop up a tree. Taxon, 51: 31-41. Brummit W. 2008. Evolution in taxonomic perspective. Taxon, 57: 1049-1050.

Cano M.J., Jiménez J.F., Gallego M.T., Jiménez J.A., Guerra J. 2009. Phylogenetic relationships in the genus Hennediella (Pottiaceae, Bryophyta) inferred from nrITS sequence data. Plant Systematic and Evolution, 281: 209-216.

Clark B.R., Godfray H.C.J., Kitching I.J., Mayo S.J., Scoble M.J. 2009 (publ. Dec. 2008). Taxonomy as an eScience. Philosophical Transactions of the Royal Society. A. Mathematical, Physical and engineering Sciences, 367: 953-966. https://doi.org/10.1098/ rsta.2008.0190

Day E.H., Hua X., Bromham L. 2016. Is specialization an evolutionary dead end? Testing for differences in speciation, extinction and trait transition rates across diverse phylogenies of specialists and generalists. Journal of Evolutionary Biology, 29: 1257-1267.

Dayrat B. 2005. Ancestor-descendant relationships and the reconstruction of the Tree of Life. Paleobiology, 31: 247-353.

Feldberg K., Váňa J., Long D.G., Shaw A.J., Hentschel J., Heinrichs J. 2009. A phylogeny of Adelanthaceae (Jungermanniales, Marchantiophyta) based on nuclear and chloroplast DNA markers, with comments on classification, cryptic speciation and biogeography. Molecular Phylogeography and Evolution, 55: 293-304.

Funk D.J., Omland K.E. 2003. Species-level paraphyly and polyphyly: frequency, causes, and consequences, with insights from animal mitochondrial DNA. Annual Review of Ecology, Evolution, and Systematics, 34: 397-423.

Futuyma D.J. 1998. Evolutionary biology. Third Edition. Sinauer Associates, Sunderland, Massachusetts.

Gophna U. (Ed.). 2013. Lateral gene transfer in evolution. Springer, New York.

Grundmann M., Schneider H., Russell S.J., Vogel J.C. 2006. Phylogenetic relationships of the moss genus Pleurochaete Lindb. (Bryales: Pottiaceae) based on chloroplast and nuclear genomic markers. Organisms, Diversity and Evolution, 6: 33-45.

Hammer Ø. 2018. PAST, PAleontological STatistics, Version 3.22. Reference Manual. Natural History Museum, University of Oslo.

Hammer Ø., Harper D.A.T., Ryan P.D. 2001. PAST 3.22. Paleontological Statistics Software Package for Education and Data Analysis. Paleontologica Electronica, 4(1): 1-9.

Hansen T.F., Houle D. 2008. Measuring and comparing evolvability and constraint in multivariate characters. Journal of Evolutionary Biology, 21: 1201-1219.

Harris J., Hobbs R.J., Higgs E., Aronson J. 2006. Ecological restoration and global climate change. Restoration Ecology, 14: 170-176.

Haskell D.G., Adhikari A. 2009. Darwin's manufactory hypothesis is confirmed and predicts the extinction risk of extant birds. PLOS One, 4(5, ef460): 1-6.
Hörandl E. 2006. Paraphyletic versus monophyletic taxaevolutionary versus cladistic classifications. Taxon, 55: 564-570.

Hörandl E. 2010. Beyond cladistics: Extending evolutionary classifications into deeper time levels. Taxon, 59(2): 345-350.

Ignatov M.S., Kuznetsova O.I., Ignatova E.A. 2019. Hybridization in mosses and how remote it can be. Biology Bulletin Reviews, 9(3): 267-273.

Jenner R.A. 2018. Evolution is linear: Debunking life's little joke. Bioessays, 40(1): 1700196. https://doi.org/10.1002/ bies. 201700196

Kirschner M., Gerhart J. 1998. Evolvability. Proceedings of the National Academy of Sciences (USA), 95: 8420-8427.

Köckinger H., Werner O., Ros R.M. 2010. A new taxonomic approach to the genus Oxystegus (Pottiaceae, Bryophyta) in Europe based on molecular data. Nova Hedwigia. Beiheft, 138: 31-49.

Kučera J., Ignatov M.S. 2015. Revision of phylogenetic relationships of Didymodon sect. Rufiduli (Pottiaceae, Musci). Arctoa, 24: 79-97.

Kučera J., Košnar J., Werner O. 2013. Partial generic revision of Barbula (Musci: Pottiaceae): Re-establishment of Hydrogonium and Streblotrichum, and the new genus Gymnobarbula. Taxon, 62: 21-39.

Kučera J., Blockeel T.L., Erzberger P., Papp B., Soldan Z., Vellak K., Werner O., Ros R.M. 2018. The Didymodon tophaceus complex (Pottiaceae, Bryophyta) revisited: new data support the subsecific rank of currently recognized species. Cryptogamie, Bryologie, 39: 241-257.

Lake P.S. 2012. Resistance, resilience and restoration. Ecological Management Restoration, 14: 20-24.

Lee J.A., Marx C.J. 2019. Tales from the crypt(ic). Science, 365: 318-319.

Magdy M., Werner O., McDaniel S.F., Goffinet B., Ros R.M. 2015. Genomic scanning using AFLP to detect loci under selection in the moss Funaria hygrometrica along a climate gradient in the Sierra Nevada Mountains, Spain. Plant Biology, 18: 280-288.

Messer P.W., Ellner S.P., Hairston Jr.N.G. 2016. Can population genetics adapt to rapid evolution? Trends in Genetics, 32: 408-418.

Moritz C., Schneider C. J., Wake D.B. 1992. Evolutionary relationships within the Ensatina eschscholtzii complex confirm the ring species interpretation. Systematic Biology, 41: 273-291.

Morrison D.A. 2010. Using data-display networks for exploratory data analysis in phylogenetic studies. Molecular Biology and Evolution, 27: 1044-1057.

Morrison D.A. 2014. Is the Tree of Life the best metaphor, model or heuristic for phylogenetics? Systematic Biology, 53: 628-638.

Palmer M.A., Falk D.A., Zedler J.B. 2006. Ecological theory and restoration ecology. In: Foundations of restoration ecology, the science and practice of ecological restoration series. $2^{\text {nd }}$ ed. Eds D.A. Falk, M.A. Palmer, Island Press, Washington, D.C., USA, pp. 1-10. 
Pennisi E. 2019. Genomics guides help for dwindling species. Science, 365(6450): 210. https://doi.org/10.1126/ science.365.6450.210

Perry L.G., Reynolds L.V., Beechie T.J., Collins M.J., Shafroth P.B. 2015. Incorporating climate change projections into riparian restoration planning and design. Ecohydrology, 8: 863-879.

Rieseberg L.H., Brouillet L. 1994. Are many plant species paraphyletic? Taxon, 43: 21-32.

Shaw A.J. 2000. Molecular phylogeography and cryptic speciation in the mosses, Mielichhoferia elongata and M. mielichhoferiana (Bryaceae). Molecular Ecolology, 9: 595-608.

Shaw A.J. 2001. Biogeographic patterns and cryptic speciation in bryophytes. Journal of Biogeography, 28: 253-261.

Shaw A.J., Werner O., Ros R.M. 2003. Intercontinental Mediterranean disjunct mosses: morphological and molecular patterns. American Journal of Botany, 90: $540-550$.

Spagnuolo V., Terracciano S., Giordano S. 2009. Clonal diversity and geographic structure in Pleurochaete squarrosa (Pottiaceae): different sampling scale approach. Journal of Plant Resolution, 122: 161-170.

Thompson J.N. 2013. Relentless evolution. University of Chicago Press, Chicago.

Vanderpoorten A., Shaw A.J. 2010. The application of molecular data to the phylogenetic delimitation of species in bryophytes: A note of caution. Phytotaxa, 9: 229-237.

Vilnet A.A., Konstantinova N.A., Troitsky A.V. 2008. Phylogeny and systematics of the genus Lophozia s. str. (Dumort.) Dumort. (Hepaticae) and related taxa from nuclear ITS1-2 and chloroplast trn $L-F$ sequences. Molecular Phylogenetics and Evolution, 47: 403-418.

Werner O., Köckinger H., Magdy M., Ros R.M. 2014. On the systematic position of Tortella arctica and Trichostomum arcticum (Bryophyta, Pottiaceae). Nova Hedwigia, 98: 374-293.

Werner O., Köckinger H., Jiménez J. A., Ros R.M. 2009. Molecular and morphological studies on the Didymodon tophaceus complex. Plant Biosystems, 143(Suppl.): S136-145.

Werner O., Ros R. M., Cano M.J., Guerra J. 2004. Molecular phylogeny of Pottiaceae (Musci) based on chloroplast rps4 sequence data. Plant Systematic and Evolution, 243: $147-164$.

Werner O., Ros R.M., Grundmann M. 2005. Molecular phylogeny of Trichostomoideae (Pottiaceae, Bryophyta) based on nrITS sequence data. Taxon, 54: 361-368.
Zander R.H. 2008a. Evolutionary inferences from nonmonophyly of traditional taxa on molecular trees. Taxon, 57: $1182-1188$.

Zander R.H. 2008b. Statistical evaluation of the clade "Rhabdoweisiaceae." Bryologist, 111: 292-301.

Zander R.H. 2009. Evolutionary analysis of five bryophyte families using virtual fossils. Anales del Jardín Botánico de Madrid, 66: 263-277.

Zander R.H. 2010. Taxon mapping exemplifies punctuated equilibrium and atavistic saltation. Plant Systematic and Evolution, 286: 69-90.

Zander R.H. 2013. Framework for post-phylogenetic systematics. Zetetic Publications, St. Louis.

Zander R.H. 2014a. Classical determination of monophyly, exemplified with Didymodon s. lat. (Bryophyta). Part 1 of 3, synopsis and simplified concepts. Phytoneuron, 201478: $1-7$

Zander R.H. 2014b. Classical determination of monophyly, exemplified with Didymodon s. lat. (Bryophyta). Part 2 of 3, concepts. Phytoneuron, 2014-79: 1-23.

Zander R.H. 2014c. Classical determination of monophyly exemplified with Didymodon s. lat. (Bryophyta). Part 3 of 3, analysis. Phytoneuron, 2014-80: 1-19.

Zander R.H. 2014d. Support measures for caulistic macroevolutionary transformations in evolutionary trees. Annals of the Missouri Botanical Garden, 100: 100-107.

Zander R.H. 2016. Macrosystematics of Didymodon sensu lato (Pottiaceae, Bryophyta) using an analytic key and information theory. Ukranian Botanical Journal, 73(4): 319-333. https://doi.org/10.15407/ukrbotj73.04.319

Zander R.H. 2017a. Anoectangium sikkimense (Pottiaceae, Bryophyta) new to the New World from Alaska, and its macroevolutionary relationships. Bryologist, 120: $435-440$

Zander R.H. 2017b. Oxystegus daldinianus (Pottiaceae, Bryophyta) new to the New World, evaluated with two new tools for floristics. Bryologist, 120: 51-57.

Zander R.H. 2018. Macroevolutionary systematics of Streptotrichaceae of the Bryophyta and application to ecosystem thermodynamic stability. Edition 2. Zetetic Publications, St. Louis.

Zander R.H. 2019a. Macroevolutionary evaluation methods extended, consolidated, and exemplified with Anoectangium (Pottiaceae, Bryophyta) in North America and the Himalayas. Annals of the Missouri Botanical Garden, 104: 324-338.

Zander R.H. 2019b. Macroevolutionary versus molecular analysis: Systematics of the Didymodon segregates Aithobryum, Exobryum and Fuscobryum (Pottiaceae, Bryophyta). Hattoria, 10: 1-38.

Recommended for publication by S.L. Mosyakin 